\title{
ADOPTION OF ETHNIC CUSTOMARY SYSTEM (ADAT) IN MODERN CONFLICTION RESOLUTION1
}

\author{
Taufik SIREGAR \\ Faculty of Law, Universitas of Medan Area Medan, Indonesia \\ sammatondang68@gmail.com
}

\begin{abstract}
Modern mediation needs the ethnic cultural tradition of conflict disputes resolution as a model, and Indonesia is rich of ethnic cultural mediation which basically can be adopted in resolving disputes. Additionally, customary law (Adat) as a legal system has its own pattern in resolving disputes. This paper sought the customary law in conflict resolution which was based on the ethnic culture mediation practices. Adat practices in mediation that had been derived from values, patterns of thoughts and norms noware getting rise to be fundamental sources of national law.Dispute resolution through customary law mechanisms had been done through deliberations that shaped the form of mediation, negotiation, facilities and arbitration. These four models of dispute settlement had been often practiced by indigenous peoples in resolving their disputes. Therefore, customary law (adat) communities have religious, communal, democratic and spiritual values. The philosophy of disputes settlement among ethnic communities in Indonesia was identified in the form of ritual ceremonies and continued as social practices of rooted cultural mediation. The findings of this research suggest courts, leaders and others to bring the conflict to a culture mediation dispute resolution.
\end{abstract}

Keywords:Mediation, Ethnic Culture, Conflict Resolution, Adat

\section{INTRODUCTION}

Asian culture has many systems which may play an important role in resolving disputes (Barnes, 2007). Ethnic groups in Asia (Matondang, 2012 and 2016) often prepare their tradition in conflict resulution instead of going to the national courts. Ethnic groups in Asia are rich of wisdoms and mediation models. Customary law has unique characteristics compared to other legal systems. Customary law is born and grows from the community, so its existence is united and can not be separated from society. According to Julie and Dominic (2009) customary law is considered as a set of established norms, practices and usages derived from the lives of people. While Zaman \& Upadhaya (2016) state thatthe customary laws are the traditional unwritten laws, which are transmitted orally from preceding generation to succeeding generation continuing from time immemorial. In recent times, the customary laws have assumed particular significance in indigenous societies brought under the traditional court for dispensation of justice. Customary law is structured and built on values, norms and norms agreed upon and believed to be true by indigenous communities. Thus, customary law is a phenomenological jurisical form of indigenous and tribal peoples.

Customary law in Indonesia or adat is the embodiment of Indonesian socio- cultural life. It has been living on the minds of the Indonesians. This paper reported the progress of customary law in comparison with the national one which was generated from Dutch colonial system. Moreover, Soedarsono (1998) mentions that the Indonesian customary law is different from other legal systems such as Roman law under Dutch colonial to Indonesia, or Indian Hindu law, Islamic legal system and various other laws. Differences of Indonesian customary law with other laws are very natural, because Indonesian society has many ethnic groups and those have their own views and philosophy of community life. Thus, Soepomo (1998) states that customary law is a manifestation and a real legal feeling of the people. Customary law is built from cultural materials both real and unreal of the Indonesian nation in particular and the Malay people in general.

Customary law as a system that relies on the nature of the mind of the Indonesian nation has the basic conceptions, elements, parts, concentrations and completeness which all constitute a unified entity. Moreover customary law regulates re-source access, there are traditional authorities who administer, 
interpret and shape customary law for the community (Mjoireman\&Meitzner, 2016). In a gradual process, which Van Vollenhoven in 1919 characterized as 'a century of injustice', local adat rights to village land were systematically curtailed, creating considerable legal uncertainty and much resentment (von Benda-Beckmann \& von Benda-Beckmann, 2011). Van Vollenhoven mentioned the construction of customary law in the community, private body, government and judiciary, family law, marriage, inheritance, land, accounts payable, and sanction system. Systematics and construction colored the values and realities of society. Indigenous and tribal peoples are the frameworks where customary law works so that it will have much influence over other parts and also affect the enforcement of customary law.

The settlement of disputes in indigenous and tribal peoples were based on a view of life within the community itself. This view of life can be identified from the distinctive features of customary law communities with modern societies. In the study of society, experts tend to divided two poles of Indonesian society; one was labeled as Indigenous agrarian and another categorized as modern which labeled industrial one. This distinction is based on the views and philosophies of life adopted by each society. In-depth analysis of the traditional settlement of disputes within indigenous peoples is largely determined by the views and characteristics of indigenous peoples.

\section{The Law Enforcement}

Bagir Manan (2005) argues that law enforcement as a concrete form of legal application greatly influences the real feeling of law, legal satisfaction, legal benefit, or legal justice individually or socially. In reality, however the law enforcement can not be separated from the rule of law, legal actors including law enforcement;itmightnot be solving the problems of law enforcement, let alone the administration of justice has much limitation.

In the context of law enforcement, Soekanto (2008) argues that the core and meaning of law enforcement lies in the activities of harmonizing the relationships of values that are outlined in steadfast rules and acts as a series of final value stages, to create, maintain and maintain peace association of life.

The above assumptionshave at least three main elements of the law enforcement such as the norms (norms of its implementation) of law or application of law and the results achieved in form of peace in society. The attainment of effective law enforcers, in the sense of law enforcement that contains certainty, justice and benefit, needs to be addressed issues related to the enforcement of the law in question. The principal issue of law enforcement lies in the fact that it influences (Soekanto,2008), that is the legal factor itself. Soekanto, in his writings on subfactors of the law limits the law, such things can be understood because the law as proposed by Peter Badura (in Hamid, 1990), is the basis and limit for government activities that ensure state demands under the law.

\section{Views of Life}

The view of life or lebensaachuung, is an objective view of the people in society about what and how the world and life. From here arises interpretation and assessment of everything faced daily. This view becomes the basis for the formulation of values or rules governing induvidu behavior in society. The view of life gives value to everything that it encounters in life. Assessment is a variety of content, which in the outline contains good judgment, bad, important, not important and so forth. In regard to indigenous and tribal peoples, the worldview gives birth to customary values and customary ideals.

Koesnoe, mentioned that the worldview of indigenous peoples is based on the philosophy of human extension. Man is as a species and he is a creature who always lives together with his nature. In the view of human custom, it is not seen as an individual being, but as a communal being. As a species, human extension can not be separated from the group in which it jointly organizes life. This view of life is called the view of togetherness as opposed to an individual view (Koesnoe, 2005).

In the principle of equality, the problem arises is how between all the same can survive into a wholeness and gain a life together really form as a whole. This statement can be answered on the principle that human beings are equal. Co-existence can be maintained based on the principle of 
"harmonious", the teaching of life together (Hadikusuma, 1992). In indigenous peoples, living in harmony is affirmed that the relationships of all citizens in the group are mutually devoted, guarded, loved and respected. In summary, one human being is a servant of another human being and not as in the western legal view of "homo homini lupus" which means that one man is a wolf for another. This view describes the atmosphere of conflict in western society.

From such views, doctrines, and basic principles, there is a very noble ethic, the sacrifice of togetherness which is a sacred calling. By practicing the sacrifice of togetherness, there will be an orderly, peaceful, peaceful, prosperous and prosperous society. This is stated explicitly, the view of life adopted by indigenous and tribal peoples.

\section{Characteristics of Customary Law}

Indigenous peoples' views of life derived from values, patterns of thoughts and norms have given rise to the characteristics of indigenous and tribal peoples. Imam Sudiyat (2005) mentions the customary law communities have religious, communal, democratic and spiritual values. Even some other researchers identify the nature of indigenous and tribal peoples with religios-magic, cash, concrete / visual, dynamic.

Religios-magic means the life of the individual's inner self in the society of customary law, is a unity with the whole society, the whole of nature and together with other creatures. Human life is not known for the distinction and separation between the world of birth and the unseen world, between humans who are still alive with the spirits of ancestors and other creatures. The main task of customary law is to foster harmony, balance, harmony and continuity between the living and living communities with the content of the universe, because the harmony will bring happiness to the common life. Any deeds that may cause disharmony, should be sought by the blessing of the invisible inhabitants.

Indigenous and tribal peoples are communal, meaning that every individual is "obliged" to uphold social rights in his community. Attitude and one's treatment is a reflection of the soul and spirit of the community. Taylor in Paradies (2016) stated that much more recently, indigenous people have begun to mark out our own discursive space in which to debate the meaning of indigeneity in Contemporary Australia. Attitude and behavior of a person is a reflection of the soul and spirit of society. The personal value of the individual is determined by his / her position and responsibility in the common life. In the life of indigenous people, things and people function socially. Help and mutual cooperationare a breath in everyday life. Transactions that result in the law can not be separated from positive moral judgments. In the modern era, the process of individualization has also haunted the life of indigenous and tribal peoples, so we must try to keep the modernization going by the collective spirit and cooperative spirit.

Indigenous and tribal peoples have a democratic nature on which mutual interests take precedence, without neglecting or harming individual interests. The atmosphere of democratic and just social life goes hand in hand with communal spirit and mutual assistance in indigenous and tribal peoples. Democratic behavior is imbued by the principle of customary law of universal value. This value is the rule of law, the principle of deliberation and representation in the system of government.

In indigenous and tribal peoples, moral and spiritual values have the highest place but do not mean to negate material interests. The pursuit of intelligence, skill, position and wealth must be based on a strong moral provision. Moral and spiritual values have an impact on the life of a simple and simple indigenous people. The nature and attitude of the fair, simple, not artificial and all-proportional attitude apda generally upheld by indigenous peoples. This attitude does not mean that the attitude of indigenous and tribal peoples is weak, static and not progressive or trampled, but this attitude is indicated as a form inconsistent with the value of humanity adopted, the customary law community will cause surprise, rebellion and resistance that does not know compromise making it very difficult to stop. 


\section{Customary Figures as Dispute Resolution}

In understanding the tradition of dispute resolution within indigenous and tribal peoples, it is necessary to understand the philosophy behind the disputes and the effects of disputes on the values and communities of indigenous and tribal peoples. Philosophy is very important to know in order to understand the decisions taken by the customary holder (customary leaders) in resolving the dispute. Philosophical considerations based on a view of life become very important because it measures the level of justice, peace, sacrifice and prosperity felt by indigenous peoples for the decisions taken (Hadikusuma, 1992).

Tradition of dispute resolution of indigenous and tribal peoples is based on the value of communal philosophy, sacrifice, supernatural value and justice (Syamsuddin, 1996). In a common law community, the common interest is a philosophy of life that permeates on the chest of every member of society. The common interest is upheld that exceeds the interests of the individual so that in the adat community, there is a common interest. If mutual interests are realized then individual interests are not trampled on. Indigenous and tribal peoples in their consciousness always attach importance to communal interests, and prevent the intervention of individual interests in their social life. Disputes that occur between individuals and groups, in the view of indigenous and tribal peoples are acts that interfere with common interests (communal) and therefore must be quickly resolved wisely by using the pattern of customary settlement (Muhammad, 1995).

Disputes that occured in indigenous and tribal peoples sometimes would appearto be settled in the public sphere and in the private sphere. In civil disputes for example, indigenous and tribal peoples continue to see that the disruption of the dispute is not only individual interests but also in their communal values and communal life. Despite civil disputes, indigenous and tribal peoples also used public intervention in their settlement, because the disturbed was not only personal interests (individuals), but also community (communal). Indigenous peoples, always uphold the value of communality, when it was compared with individual values. Yet if we used the European legal system, civil disputes were not a public domain in the settlement.

\section{The Philosophy of Customary Law}

The sacrificial philosophy of dispute settlement was an emphasis point in indigenous and tribal peoples. The parties to the dispute, whether in the private or public sphere, must have the willingness to sacrifice individual interests for the sake of communal interests. The settlement of disputes with customary patterns reflected the value of the community that had to be accepted by the conflicting individual, with the realization that they are part of the other. They are shared in both species and parts of indigenous and tribal peoples. The customary law's decision was taken in resolving disputes to be an umbrella that maintained the value of togetherness. Therefore, the parties to the dispute were willing to withdraw and sacrifice in order to preserve the values and customary order which they uphold. The willingness to sacrifice for communal and self-contained interests dominates the interests of the individual will receive more respect and ethical values than indigenous and tribal peoples. Conversely, those who consider communal interests and far more concerned with individual interests tend to get negative judgments from indigenous and tribal peoples and may lead to adat sanctions.

The supernatural philosophy of dispute settlement in indigenous and tribal peoples had been long identified in the form of ritual ceremonies. The goal was that the parties to the dispute need to gain recognition from the supernatural in its resolution. Therefore, the sincerity of the parties was to sit together to resolve the disputes that plagued them, and facilitated by the traditional leaders was regarded as the will of the Almighty. The existence of spiritual values was derived from the ritual ceremony indicatedthat the dispute settlement had a surprise and monitoring from the supernatural. The parties were not free to return to the conflict after their dispute was resolved through a customary pattern (Muhammad, 1995).

The philosophy of justice to be enforced in the settlement of disputes among indigenous peoples formed a communal justice. Communal justice made no one got aggrieved by the decision taken by the chairman or traditional leader in resolving the dispute. This justice played an very important role to uphold as the joint of the life order of society. The dignity and prestige of indigenous and tribal 
peoples had been largely determined by the degree to which the values of communal justice are manifested. The higher the value of communal justice, the stronger and noble the position of the law community(Adat).

The founded philosophies were the base of tradition and dispute resolution in indigenous and tribal peoples. Settlement of disputes within indigenous and tribal peoples had been determined by customary law values, adat leaders and customary institutions. The values of customary law were the norms that become the standard of behavioral patterns of indigenous and tribal peoples. This value also served as a guide for customary leaders in carrying out their duties to resolve disputes. Indigenous leaders were people who had "customary charismatic" and understood the customary laws that had been derived in descending order. They became the referral of dispute settlement in the customary law community. Customary law is in their hands and it is they who inherit customary law and enforce it in the life of indigenous peoples. Those who understand and master the norms of customary law were so called adat leaders who played as leaders in indigenous and tribal peoples. Additionally customary institutions had specific duties and functions to maintain the customary law practices in the society.

\section{Customary Pattern as a Dispute Settlement}

Tradition of dispute settlement in indigenous and tribal peoples which was so "customary patterns" or in other terms often called "familial" patterns. This patternwas not only to be implemented for the civil disputes, but it also was applied to criminal case. The settlement of disputes with customary patterns did not mean there was no compensation or punishment whatsoever against customary law-breakers. Penalties were in force both in corporal punishment and property compensation. The application of this penalty depended heavily on the type and severity of disputes that occured between the parties. It is important to point out here that the essence of dispute resolution in customary law is to realize peace in a comprehensive sense. Peace is meant here not only for the parties or perpetrators and victims but peace for the community as a whole. Therefore, the approach used was a persuasive approach to dispute resolution using the language of adat and religion so that the awareness of the parties emerges that there was no meaning to living in the world in case of disputes and actions that harm others. The objective of dispute settlement in customary punishment was permanent peaceful manifestation.

Indigenous and tribal peoples prefer the settlement of disputes through deliberative channels aimed at bringing about peace within the community. Deliberation was the main path used by the customary law community to resolve the dispute because in the deliberation will be made a peace agreement that benefits both parties. The use of deliberations and customary court proceedings was used to be dominated by deliberative approaches in resolving conflicts over disputes. It was found that the deliberation tobe one of the essences phisosophy and characteristics of indigenous and tribal peoples.

In the customary law system, the legal division of public and private laws had not practiced. As a result, indigenous and tribal peoples were not familiar with the categorization of criminal and civil law as in the Continental European legal system. The term disputes for indigenous and tribal peoples was not only intended for civil cases that focus on individual interests, but disputes were also used for criminal offenses. Hence the dispute regulation for indigenous and tribal peoples, aimed at social imbalances, meaning that if there was a dispute in civil law or crime and violation of criminal law, the customary law community would feel that there had been an imbalance in the life of indigenous people. Therefore, the community used to resolve the dispute through customary law mechanisms.

Customary leaders improved and rehabilitated the social imbalancesof conflicts or disputes in indigenous and tribal peoples. Proactive customary leaders or stakeholders maintained and created social harmony in indigenous and tribal peoples. Therefore, the adat stakeholders tackled a dispute between the parties, then they obliged to offer the resolved disputes through deliberation or mediation. The adat stakeholders used the mediation path to safeguard the humanitarian and social values of the disputing parties, as dispute settlement through mediationmaintained the dignity of the individual as a member of the community. In mediation, no party wins and losers and even mediation provided the parties the freedom to create their own concrete forms of dispute resolution. The parties had more proactive condition in submitting their demands or interests in the mediation process so that the agreement made would notresult in disadvantaged by the other party (Muhammad, 1995). 
Dispute resolution through customary law mechanisms had been done through deliberations that shaped the form of mediation, negotiation, facilities and arbitration. These four models of dispute settlement had been often practiced by indigenous peoples in resolving their disputes. Customary leaders perform their functions as mediators, facilitators, negotiators and arbiters. In practice, adat leaders generally use this approach jointly, especially in resolving private and public disputes.In indigenous and tribal peoples, mediation was used to resolve criminal cases. For example, in case of torture or murder, the adat leader settled the case by approaching both the victim and the perpetrator and the perpetrator's family. The involvement of the family playeda very important role because in indigenous and tribal societies there was a familial bond, and it had a strong binding relationship among members of a relative. Thus, it was found that the scope of mediation within indigenous and tribal peoples was not limited to private conflicts but it was also applied to solve public cases. The use of mediation, arbitration, negotiation and facilitation has been much broader in customary law when it is compared to a positive law in Indonesia.

The mediation was carried out by customary leadersthose whohad the power to resolve disputes, both in private and public sphere disputes. Mediation as a form of dispute resolution has been practiced by indigenous and tribal peoples as ancestral heritage. This heritage is preserved for generations because the value of mediating philosophy restores human function as part of nature that requires balance and harmony. Conflict or disruption has disrupted the balance of human life as a social being. Mediation makes the disputing parties reintegrate, living harmoniously and reinforcing the kinship after being shaken by conflicts or disputes, not only the duty of indigenous stakeholders or community leaders, but it is obligatory for every individual who becomes a member of the customary law community. This obligation arises because individuals in indigenous and tribal peoples are guarding communal interests.

Indigenous communal law communities emphasized that the individuals in disputes should strive to create social harmony and dispute disputes. If a member not endeavoredit and was unwilling to settle the dispute through mediation, then the individual was labeled in anegative judgment from his communal community. Therefore, mediation has a profound power as an alternative to dispute resolution in the life of indigenous and tribal peoples.

The existence of disputes in indigenous and tribal peoples shaped one form of action that had already interfered with communal interests. If in a society there was a dispute then the "social feeling of pain" was not only felt by the individual in dispute but also felt by all members of the customary law community. Indigenous leaders as the embodiment of the values and social feelings of indigenous and tribal peoples acted to preserve social feelings and eliminate the "pain" caused by disputes that occured among the parties.

\section{CONCLUSION}

The mediation process in accordance with the indigenous norm in principle has the below procedures:

a) The dispute party may request assistance to a third party (mediator) to resolve their dispute. The mediator was entrusted by the parties (he had been generally a traditional figure);

b) Those who gave any confidence to indigenous leaders as mediators were based on the trustworthy that they were selected people who had the authority, respectable, charismatic in their words and should be the ones who were able to kept the secret meetings of the disputes between the parties.

c) Indigenous leaders who had any confidence of mediating, approached the cases in refer to the values of costumary language, so that the disputants might sit together explained the background of the conflicts of the disputes, and the possibilities of finding a way out to end the disputes.

d) Indigenous leaders as mediators hold a number of meetings; including separate meetings; if needed or involved other independent tribe leaders after obtaining approval from both parties. 


\section{REFERENCES}

Barnes, Bruce E (2007) Culture, Conflict, and Mediation in Asian Pacific, University Press of America: Toronto New York

Hadikusuma, Hilman (1992) Introduction to Indonesian Traditional Law Science, Bandung: Mandar Maju, p. 35

Hamid, A.S. Attamimi (1990). The Role of Presidential Decree of the Republic of Indonesia in the Implementation of State Administration. Dissertation, Faculty of Post Graduate University of Indonesia, Jakarta, p.334

Paradies, Y. (2016). Beyond black and white: Essentialism, hybridity and indigeneity. In Handbook of Indigenous Peoples' Rights (pp. 44-54). Routledge.

Joireman, S. F., \& Meitzner Yoder, L. S. (2016). A Long Time Gone: Post-conflict Rural Property Restitution under Customary Law. Development and Change, 47(3), 563-585.

Julie A. Davis and Dominic N. Dagbanja (2009) " The Role and future of Customary Tort Law in Ghana: A cross-Cultural Perspective" Arizona Journal of International and Comparative Law, Vol. 26. No.2 303

Koesnoe, M.(2005)Towards Customary Law Theory, in M. Syamsudin, et al. (editor), p.61-62.

Manan, Bagir(2005)Law Enforcement Justice, Varia Justice Magazine, No.241. Ikahi, Jakarta. p.4

Muhammad, Bushar, (1995) Principles of Customary Law, Pradnya Paramita. Jakarta.

Matondang, Saiful Anwar (2012). Interethnic Peception of Ethnic Boundaries in Penang Malaysia: University of Hawai'i Honolulu USA

Matondang, Saiful Anwar (2016) The Revival of Chinessness as Cultural indentity in Malaysia, Khazar Journal of Humanities and Social Sciences, No.19. Vol. 4.

Syamsuddin, M (1996) Perkembangan Konsep Hukum Adat dari Konsepsi Barat ke Konsepsi Nasional (Sebuah Tinjauan Historis), JURNALHUKUM. N0.5. VOL

Sudiyat, Imam(2005)The development of several Fields of Traditional Law as Modern Classical Law, in M. Syamsudin, et al., p.29-31.

Soedarsono, R.H.(1998) Study of Customary Law in M. Syamsudin, et al. (Editor), Customary Law and Moderation of Law, Yogyakarta: FH UII, p.5-6

Soekanto, Soerjono(2008)Factors Affecting Law Enforcement. Eagle. Jakarta, p. 5

von Benda-Beckmann, F. \& von Benda-Beckmann, K. (2011). Myths and stereotypes about adat law: A reassessment of Van Vollenhoven in the light of current struggles over adat law in Indonesia. Bijdragen tot de taal-, land-en volkenkunde/Journal of the Humanities and Social Sciences of Southeast Asia, 167(2-3), 167-195.

Zaman, A., \& Upadhaya, B (2016) Administration of Justice and Customary Law among the Shertukpen of Arunachal Pradesh. Indian Journal of Research in Anthropology, 2(2), 135. 